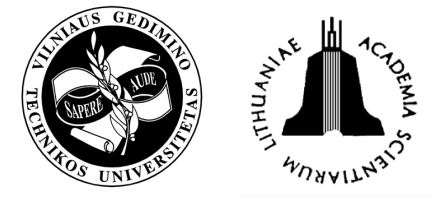

\title{
THE INFLUENCE OF TURPENTINE ADDITIVE ON THE ECOLOGICAL PARAMETERS OF DIESEL ENGINES
}

\author{
Algis Butkus ${ }^{1}$, Saugirdas Pukalskas ${ }^{2}$, Zenonas Bogdanovičius ${ }^{3}$ \\ Dept of Automobile Transport, Vilnius Gediminas Technical University, \\ J. Basanavičiaus g. 28, LT-03224 Vilnius, Lithuania \\ E-mails: ${ }^{1}$ tiauto@ti.vgtu.lt, ${ }^{2}$ saugirdas.pukalskas@ti.vgtu.lt, ${ }^{3}$ psichlab@ti.vgtu.lt \\ Received 1 December 2006; accepted 1 February 2007
}

\begin{abstract}
After Lithuania's accession to the EU it is very important to use a larger amount of renewable fuel. Based on economic and environmental considerations in Lithuania, we are interested in studying the effects of turpentine contents in the blended turpentine-diesel fuel on the engine performance and pollutant emission of compression ignition (CI) engine. Therefore, we used engine test facilities to investigate the effects on the engine performance and pollutant emission of $5 \%$ turpentine in the fuel blend. The tests were carried out in the laboratory on an engine dynamometer of the car Audi $1 Z$ and tractor $D 21$ diesel engines. The experimental results showed that turpentine used in the fuel blend for these diesel engines had a positive influence on the engine performance and exhaust emission.
\end{abstract}

Keywords: alternative fuel; renewable fuel; turpentine; diesel engine; internal combustion engines; exhaust emission.

\section{Introduction}

The internal combustion engines which were invented in the last decades of the 19th century began to influence on human activities and environment in the beginning of the 20th century. At the end of the century the air pollution with combustion products and immoderate consumption of energy recources became unbearable.

R. Diesel, a professional engineer, at first used kerosene from lightening lamps for his engine and later he experimented with natural oil. The latter proved to be too viscous for pneumatic spraying (the engine of mixed working cycle became usable when Bosch company made a high-pressure injection pump in 1922).

In the 1930s the appearance of variety of Diesel engine combustion spaces and fuel injectors was forced by lack of light fuels (petrol) because the raw oil was distilled in classical manner.

Theoretical examination of fuel micro drops inflammation in the environment of the compressed and so heated air ascertains that every combustible liquid is inflammable and able to rapid combustion $[1,2]$. The goal is to reach a complete oxidizing of the injected portion of the fuel in the compact space. Aggressive sulfurous fuels are harmful to engines as well as to environment. How all requirements ought to be matched? Today there is no alternative to use the Diesel engine as a transformer of the heat energy to the mechanical one in transport because of its portativity, quick start, not complicated production. The cheapest way of fuel and environment saving there would be some limitation of the engine use (e. g. in case the pe- destrians walked to their jobs, it would be more useful for their health and for the environment than to wait in traffic jams if going by car).

It was established by prof. Bernhardt experiments, that increase of engine power of tractor engines results in only $2 . .3 \%$ increase of average speed, however the exhaust emission there increases by several times.

\section{Goal and method of the research}

Preliminary tests of turpentine as a harmless renewing additive to fuel and its influence on ecological and economic indications of Diesel engines are the goal of this research. The research was based on comparison of the engine operation with pure diesel fuel and diesel fuel with $5 \%$ of turpentine additive.

The turpentine (EB No. 232-350-7) is a product of natural organic combinations. The general formula of turpentine is $\left(\mathrm{C}_{5} \mathrm{H}_{8}\right)_{\mathrm{n}}$. These unsaturated carbon hydrates are indissoluble in water and of high oxidability [2]. Turpentine is a product of pine branches or a coproduct of sulphatic cellulose. Its blaze up temperature is $32 \ldots 46{ }^{\circ} \mathrm{C}$ and inflammation temperature is $253{ }^{\circ} \mathrm{C}$.

As the heating capacity of turpentine $H_{a}$ was not found in references, it was calculated in accordance with formula [3]:

$H_{a}=33.91 \cdot C_{x}+125.6 \cdot H_{x}-2.51 \cdot\left(9 \cdot H_{x}-W\right) \mathrm{MJ} / \mathrm{kg}$,

where: $C_{x}$ - percentage of carbon in the molecule; $H_{x}$ - percentage of hydrogen in the molecule; $W$ - percentage of humidity in turpentine. 
Knowing the chemical formula of turpentine $\left(\mathrm{C}_{5} \mathrm{H}_{8}\right)_{\mathrm{n}}$ and molecular weights of carbon and hydrogen (12 and 1 correspondingly) we find the heating capacity of turpentine $H_{a}$, which is equal to $42.04 \mathrm{MJ} / \mathrm{kg}$. The heating capacity of pure diesel fuel is equal to $42.5 \mathrm{MJ} / \mathrm{kg}$.

Before these tests the stability of the turpentinediesel fuel blend was examined. Different proportions $(1: 5,1: 10,1: 20)$ of the blends were observed for 14 days and neither sediment nor formation of any layers were found.

Tests were carried out in the laboratory conditions with two different Diesel engines. Drawings of their loading characteristics were created from the test results. One of the engines was the turbo diesel direct injection engine of the car Audi-80, and the second one - two cylinder direct injection air cooled tractor engine. Technical characteristics of these engines are given in Table 1.

Table 1. Technical characteristics of the tested engines

\begin{tabular}{|l|c|c|}
\hline \multicolumn{1}{|c|}{ Characteristic } & \multicolumn{2}{c|}{ Description } \\
\hline Type of engine & $1 \mathrm{Z}$ & $\mathrm{D} 21$ \\
\hline Volume, $\mathrm{cm}^{3}$ & 1896 & 2080 \\
\hline Compression ratio & 19.5 & 16 \\
\hline Power, $\mathrm{kW}$ & 66 & 14.7 \\
\hline Engine speed, $\mathrm{min}^{-1}$ & 4000 & 1270 \\
\hline Torque, $\mathrm{N} \cdot \mathrm{m}$ & 180 & 98 \\
\hline Engine speed, $\mathrm{min}^{-1}$ & $2000 \ldots 2500$ & - \\
\hline Cylinder diameter, $\mathrm{mm}$ & 79.5 & 105 \\
\hline Piston stroke, $\mathrm{mm}^{-1}$ & 95.5 & 120 \\
\hline Idle speed, $\mathrm{min}^{-1}$ & $780 \ldots 860$ & 800 \\
\hline
\end{tabular}

The electrical test bed $K И-5543$ with a balance type dynamometer was used for this research. The engines were connected directly (without a gearbox) to a shaft having constant-velocity joints on both its ends.

This test bed is an universal one. At rotating speed between 600 and $1500 \mathrm{~min}^{-1}$ it operates as an electromotor and between 1500 and $3000 \mathrm{~min}^{-1}$ it operates as an alternator. In both cases the torque of the test bed is controlled by a special rheostat of liquid type which changes the electrical current in the armature winding by help of an electromechanical drive which changes the level of dipping of the rheostat electrodes into the electrolyte.

For measuring of the exhaust gas smoke the analyzer of combustion products AVL Di Com 4000 was used. Its operation is based on the principle of photometric absorption which enables to estimate the smoke level $D$ and the absorption coefficient in the combustion products. This analyzer also indicates the oil temperature in the engine. Table 2 presents its technical features.

The fuel consumption was measured by weight with the help of electronic balance $S K-5000$ of maximum weight indications $-5000 \mathrm{~g}$, resolution $-1 \mathrm{~g}$ and surroundings temperature $--10 \ldots+40^{\circ} \mathrm{C}$. Its power supply - DC 9V or AC 220V.

For time measuring an electronic chronometer with the maximum time indications of $10 \mathrm{~h}$ and resolution of $0.01 \mathrm{~s}$ was used.

Table 2. Technical characteristics of the analyzer AVL DiCom 4000

\begin{tabular}{|l|l|l|}
\hline \multicolumn{1}{|c|}{ Parameter } & \multicolumn{2}{|c|}{ Characteristic } \\
\hline Principle of smoke measuring & absorption \\
\hline $\begin{array}{l}\text { Space of smoke measuring: } \\
\text { heating }\end{array}$ & $+100{ }^{\circ} \mathrm{C}$ \\
$\begin{array}{l}\text { real measurement distance } \\
\text { max. temperature of } \\
\text { combustion products }\end{array}$ & $0.430 \pm 0.005 \mathrm{~m}$ \\
\hline Measuring features: & $+200{ }^{\circ} \mathrm{C}$ \\
\hline exhaust gas smoke & limits of \\
measurement & resolution \\
obsorption coefficient & $0 \ldots 100 \%$ & $0.1 \%$ \\
oil temperature & $0 \ldots 99.99 \mathrm{~m}^{-1}$ & $0.01 \mathrm{~m}^{-1}$ \\
& $0 \ldots+120{ }^{\circ} \mathrm{C}$ & $1{ }^{\circ} \mathrm{C}$ \\
\hline
\end{tabular}

\section{Results}

The results of the experiments are presented in Figures $1-5$ below.

Fig 1 indicates that operation of the $1 \mathrm{Z}$ engine with diesel fuel and turpentine blend at rotational speed of $1700 \mathrm{~min}^{-1}$ with different loadings increases fuel consumption $B_{e}$ and specific fuel consumption $b_{e}$ approximately by $2 \%$ only in the vicinity of low loadings. At higher loadings consumption of the fuel blend practically does not differ from the case of pure diesel fuel.

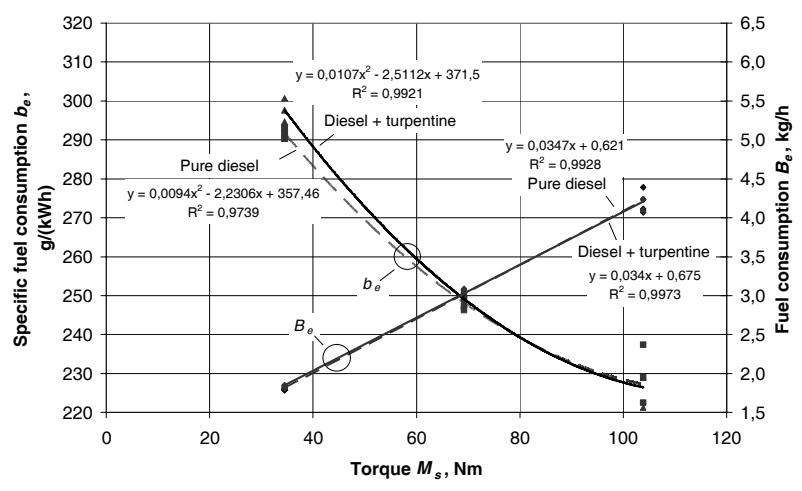

Fig 1. Dependence of fuel consumption on the engine torque for run at speed of $1700 \mathrm{~min}^{-1}$

Both of these cases are presented in Fig 2. Both graphs are highly similar. They show the fuel consumption of $1 \mathrm{Z}$ engine for its run at rotational speed of $2200 \mathrm{~min}^{-1}$. It is seen that both fuel consumption $B_{e}$ and specific fuel consumption $b_{e}$ differ imperceptibly, however they are slightly higher for engine, operating with pure diesel fuel. The greatest difference is at moderate loadings but it does not exceed $2 \%$. 


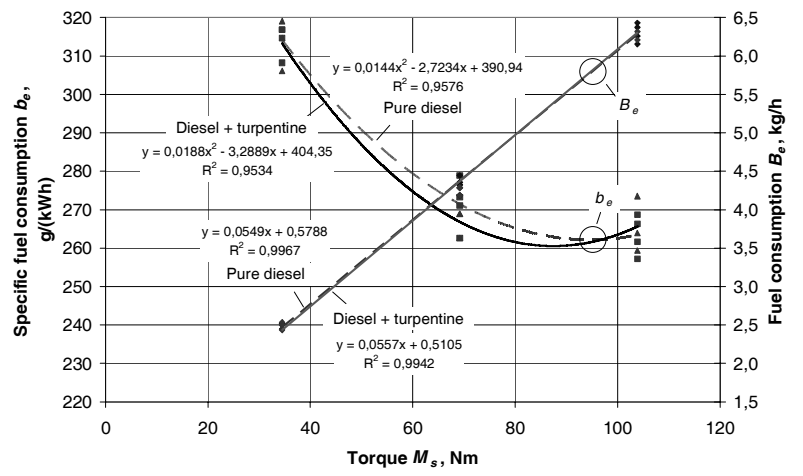

Fig 2. Dependence of fuel consumption on the engine torque for run at speed of $2200 \mathrm{~min}^{-1}$

Such imperceptible difference of the fuel consumption can be explained by similarity between values of heating capacities of pure diesel fuel and its blend with turpentine.

A small amount of turpentine additive to diesel fuel highly reduces the exhaust gas smoke. It is clearly shown in Fig 3, where results of research of engine exhaust smoke are presented for engine operation with pure diesel fuel with $5 \%$ addition of turpentine at different rotational speed.

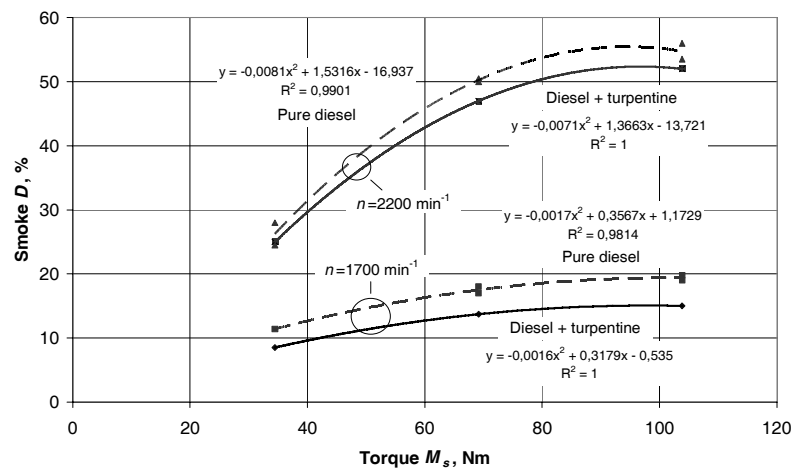

Fig 3. Dependence of exhaust gas smoke on the engine torque for run at different speed

During operation of Audi-80 $1 \mathrm{Z}$ engine with the fuel blend at rotational speed of $1700 \mathrm{~min}^{-1}$ there was observed a $20 \%$ reduction of engine exhaust smoke if compared with the pure diesel fuel case. At rotational speed of $2200 \mathrm{~min}^{-1}$ the reduction was less, by about 7...8\%.

Results of similar tests of the second engine (D21) for rotational speed of $1200 \mathrm{~min}^{-1}$ are presented in Fig 4 and Fig 5.

In general, it could be said, that addition of $5 \%$ of turpentine to the diesel fuel reduced the engine exhaust smoke by $8 \%$ in normal working conditions (Fig 5). Fuel consumption at low loading reduced by $7 \%$ but it increased by about $2 \%$ at higher loadings (Fig 4). It can be explained by less heat capacity of turpentine.

The engine exhaust smoke of D21 engine, as it is seen from Fig 5, at loadings of more than $70 \%$ in both cases increased more rapidly than at lower loadings. It was influenced by structure of combustion space and by adjuster of combustible mixture.

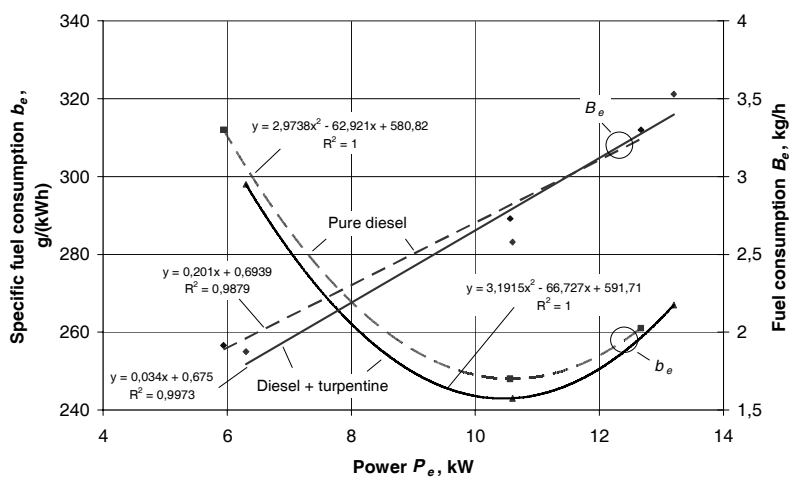

Fig 4. Dependence of fuel consumption on the engine power for run at speed of $1200 \mathrm{~min}^{-1}$

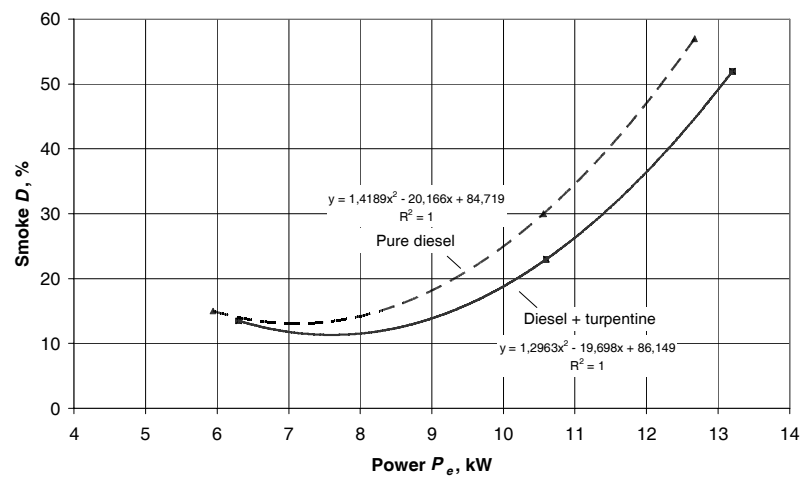

Fig 5. Dependence of exhaust gas smoke on the engine power for run with different fuels

\section{Conclusions}

1. Addition of $5 \%$ of lighter fuel fractions to diesel fuel reduced engine exhaust smoke by $10 . .20 \%$ in both Diesel engines.

2. Turpentine easily form mixtures (without any supplements) with diesel fuel.

3. Decrease of specific fuel consumption $b_{e}$ for diesel fuel blends with $5 \%$ of turpentine was caused by faster evaporation and combustion of the blend particles as compared with pure diesel fuel.

4. Small amount of turpentine additive to diesel fuel would increase the cost of the fuel blend only by $3 . .5 \%$.

\section{References}

1. BUTKUS, A.; PUKALSKAS, S. The research into the influence of ecological petrol additives in the automobile laboratory. Transport, 2004, Vol XIX, No 1, p. 24 27.

2. DIGAMBARA, P.; MISHRA, A. K. Study of diesel fuel contamination by excitation emission matrix spectral subtraction fluorescence. Analytica Chimica Acta, Elsevier, 2002, No 454, p. 209-215.

3. ALDO VIEIRA DA ROSA. Fundamentals of renewable energy processes. Oxford: Elsevier Academic Press, 2005. 690 p. 